Article

\title{
In a Search for Equity: Do Direct Payments under the Common Agricultural Policy Induce Convergence in the European Union?
}

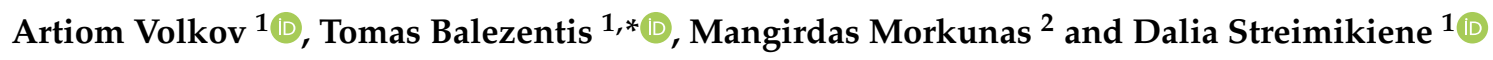 \\ 1 Division of Farms and Enterprises Economics, Lithuanian Institute of Agrarian Economics, Kudirkos 18-2, \\ LT-03105 Vilnius, Lithuania; artiom@laei.lt (A.V.); dalia@mail.lei.lt (D.S.) \\ 2 Faculty of Economics and Business, Mykolas Romeris University, Ateities 20, LT-08303 Vilnius, Lithuania; \\ morkunas.mangirdas@gmail.com \\ * Correspondence: tomas.balezentis@laei.lt
}

Received: 30 May 2019; Accepted: 20 June 2019; Published: 24 June 2019

\begin{abstract}
The European Union (EU) is an integrated alliance of equally treated Member States sharing mutual values, legal principles and markets. Close cooperation, deep integration and convergence are the major priorities for the EU. Anyway, these principles are not always reflected in the EU-wide policies which are implemented through financial support mechanisms. The direct payments financial support mechanism under the Common Agricultural Policy, the main instrument for promoting convergence in development of Member States' agricultural sectors and rural sustainability, faces critique for failing to meet its objectives. One of the major deficiencies of the direct payments scheme is that it allocates more resources to already developed agricultural sectors of the older Member States and less resources to developing ones thus increasing the divergence among the Member States. The aim of this paper is to suggest new mechanisms for direct payment funds redistribution across the EU Member States which are based on the methodological principles that would more precisely correspond to the aims of convergence, transparency and fair redistribution. The results show that, regardless of the method chosen (to support more or less effective agricultural sectors of EU Member States), the proposed methodology lowers differences in direct payment rates among the EU Member States by two-fold. This ensures correspondence to the goal of convergence within the EU.
\end{abstract}

Keywords: direct payments; Common Agricultural Policy; convergence; production costs; European Union

JEL Classification: Q11; Q18

\section{Introduction}

After its expansion in the 21st century, the European Union (EU) became strongest economic entity in the world, characterized by the highest living standards [1], and an economic policy oriented towards the creation of the welfare state with decreasing inequality. However, despite being a union of closely interrelated states, the EU often embarks on policies related to contradictory objectives and has not eradicated the imbalances in economic competitiveness, quality of life, and infrastructural development existing between the old and new Member States. To address this challenge, almost one third of the EU budget is allocated to cohesion programs implemented across the EU [2]. Amidst considerable financial support (378.9 billion EUR has been proposed for 2021-2027, out of which market-related expenditures and direct payments amount to 286.2 billion EUR) [3], administrative and legislative support from the European Commission, New Member States are still lagging behind the schedule in a convergence process. This situation not only precludes the EU citizens from enjoying 
economic benefits but also puts pressure on the whole EU in the sense of economic compatibility and effective common market as echoed by the concerns over the "two speed European Union" [4].

As regards the agricultural sector, there have been different explanations for the failure in the convergence of agricultural income. This can be attributed to insufficient technological development of the beneficiary countries [5] negative effects of the CAP on employment in rural regions [6] and declining population density in rural regions. What is more, the convergence policy is being challenged arguing that it facilitates concealed support to the old Member States [7]. Sometimes, especially in agricultural sector, these statements may look rational, as, for example, direct payments for supporting modernization farms in New EU Member States are being constructed in a way, which indirectly promotes the purchase of equipment, produced in older EU Member States [8,9]. There has been evidence of deficiencies of EU financial mechanisms from the perspective of economic convergence [10] showing capital misallocation as one of obstacles for the convergence process within the EU. Barret [11] argued that economic convergence process in the EU is behind the schedule due to deficient in democratic legitimacy of its management mechanisms, that is especially felt in agriculture [12].

In order to address the issue of convergence among the EU Member States in terms of agricultural income, the aim of this paper is to propose and test a new direct payments distribution mechanism, which is based on the principles agreed by all the EU Member States [13] The proposed mechanisms should encourage convergence between the old and new EU Member States by following clearly articulated principles. We present the theoretical considerations and apply them to establish tentative guidelines for (re-)distribution of the direct payments under the goal of convergence. This study contributes to the ongoing scientific debate [14-18] on the impact of the CAP on convergence within the EU.

\section{Theoretical Background}

\subsection{The Deficiencies of Current Direct Payments Financial Mechanism}

The shift from financial solidarity to national concerns in allocation of direct payments financial envelopes has been noted in the scientific literature $[19,20]$ Some studies [2] have found EU financial support for regional economic growth has only had a marginal effect on its economic development and further European integration. The marginal results of the EU funding onto the convergence of economically lagging regions was also found by Pellegrini et al., [21], showing the estimated time of about 50-75 years under the current financial support mechanism. Gagliardi and Percoco [22] found spatial effects of EU cohesion policy, documenting the noticeable economic growth in rural regions around big urban agglomerations and no significant effects on purely rural regions, raising the questions about the effectiveness of direct payments under CAP umbrella in corresponding to the goals stated in CAP, especially increasing convergence and sustainability of rural regions, as the abovementioned growth should be associated with relocation of economic activities from urban agglomerations to its outskirts due to lower operating costs there and increasing individual housing trend [23]. The divergence, induced by EU funding, which biggest part is being allocated to CAP, between richer urban agglomerations economies and poorer rural regions was documented also by Wójcik [24]. The negative influence of EU funding onto less developed region was found by Becker et al. [25] noticing its negative influence onto employment in regions-transfer payments receivers. The EU financial support even creates a noticeable divergence in EU regions in terms of innovation absorbing capabilities [26], that are essential in assuring sustainable economic growth. The differences in technological development and accessibility to innovations is stressed by Barath and Ferto [27] as one of the factors of different agricultural productivity levels in Old and New EU Member States. A slow convergence process between Old and New EU Member States is widely documented [28-30] Although some sectors of the economy show better results (fintech, IT and etc.) in the overall assumptions, the convergence process is lagging behind schedule [31]. The same trends are being monitored in agricultural sector [32]. 
The weakness and vulnerability of New Member States' agricultural sectors is also emphasized by Boulanger and Philippidis [19], who show that various shifts to lowering the direct payments financial support would be more felt in a new (as expected) EU Member States, sounding negatively in terms of employment and quality of life in rural regions. It also may serve as a barrier for changing the direct payments financial support mechanism, as if it would be coupled more with market driven mechanisms, it would be more independent from the political decisions in Brussels, providing New EU Member States with bigger space for manoeuvre in defending their interests.

Another objective, to counter which direct payments were introduced, is the quite low competitiveness of the EU agricultural sector. There also mixed results can be observed. From one hand, direct payments help farmers to modernize their farms, increases accessibility to innovations, ensures employment and viability of rural regions [33,34], on the other hand, the direct payments scheme, under which the amount of payments are directly related to the size of and owned lead to the accumulation of wealth in the hands of bigger landowners, increased their possibilities of acquiring additional land and become a small power centre in a rural areas acting as the only provider of work in particular areas. This land grab not only lowers the levels of rural sustainability [35], but also leads to higher land prices [36]. Once again, bigger lands represent a valuable asset that leads to the ability to borrow bigger amounts of money, which can be invested into productivity, thus increasing competitiveness and profitability. This mechanism works better the bigger direct payments are paid per agricultural unit. The method was augmented and refined in a 2013 CAP reform [37]. The difference in payments between the Old and New EU Member States manifests itself negatively in the different competitiveness levels of Old and New EU Member States agricultural sectors [38] thus increasing divergence, not convergence.

The Direct Payments serve also as an income stabilization tool [39], whose rationale is based on a fact, that farmers are subjected to various types of risks (flooding, drought, frosts, agricultural pests and etc.) that are far beyond control and can severely affect farmers income, even leading to insolvency. In order to avoid this and maintain food production dispersed among the whole $\mathrm{EU}$, as close as possible to consumption centres, the direct payments under CAP was improved making farming more financially attractive. Although it is proved that direct payments levels do not correlate to the number of hazards or risk manifestations in particular regions [40] and simply serve as unregulated internal financial aid to receiving states economies, as more than $80 \%$ of farms in the EU [41] are represented by family farms, those income is being infused into local economies on a much higher scale, than the financial support, received by industrial corporations, which in a form of dividends may be allocated out of EU. Such an indirect role, served by direct payments—-fostering of economic growth of the receiving state-may be the reason, why the direct payments in old and new EU Member States still differ significantly, even though this contradicts the principles of convergence. Although there are some evidence about New Member States accepting a second tier role: "The new Member States have "paid" their access to the EU with a sort of silent acceptance of rules, especially for the CAP, that have often been against their specific and legitimate interests (one case for all is the limited access to direct payments and the top ups)“ [42] (page 13), should not affect or distort fair competition within the EU. What is also important to mention is the direct payments role in strengthening the receiving states economy, augmented by the fact, that they support economic growth by increasing internal demand, thus increasing state's economic resilience to perturbations in international trade relations or to manifestation of mercantilist policies in particular countries. Even though highly criticized, the income support mechanism remains the most advanced tool in directing direct payment financial flows [43], so any adjustments of these transfer payments of public money must be based on the rationale of covering the costs of production of agricultural goods.

\subsection{Current Political Framework}

Following the largest EU expansion of 2004, supplemented with the 2007 and 2013 entrances of Romania, Bulgaria and Croatia, the transfer payments from the whole EU budget were shifted 
eastwards. The biggest part of EU expenditures is being allocated to CAP [44]. Direct Payments are the most intensively financed measure of the CAP. Their distribution between countries, based on poor reference indicators, what were set before the accession to EU: yield per ha, crop area and etc., has led to a situation, what for many of the new EU Member States, payments (per hectare) were set significantly lower than the EU average. The situation was particularly poor in Lithuania, Latvia and Estonia [45,46]. It is a paradoxical situation, as before entering the EU, Central and Eastern European countries did not enjoy easy access to financial capital, allowing them to modernize the respective countries' agricultural sectors to increase productivity, and their accessibility to markets was also restricted due to high tariffs, etc. Following the accession the direct payments financial support is being coupled with historically low productivity, leading to lower financial transfers compared to old Member States, thus not allowing new Member States to keep up with older ones and not increasing convergence, but serving as barrier for it [15].This situation has not changed even after ten years and is not about to change in a period of 2021-2027, although economic, structural and productivity indicators in agriculture have changed significantly [47]. Anyway, there is no discussion in the EU about changing referential years for the New Member States, although there have been questions whether it is just to consider reference years which are related to performance of the developed agricultural sectors of the Old EU Member States and those of pre-entrance for the New Member States or Candidate States which are mostly related to reduced performance developing agricultural sectors there [48]. Especially, after more than decade of membership, some countries still have not been reconsidered in terms of the reference year.

In 2021-2027 programming period, like in a previous one [49], one of the main CAP funding issues is direct payments and its redistribution among EU Member States. The relevance of the issue is determined by the share of direct payments in the total CAP budget (around 70\%) and the differences of direct payments values per 1 hectare of agricultural land (UAA) between the EU Member States. Yet during the preparations for the 2014-2020 programming period of the CAP, the European Commission has launched various programs, initiated working groups at EU level to create fairer criteria for the distribution of financial envelopes of direct payments between the EU Member States. The complexity of the selection of objective criteria was augmented by the strong and different national positions of individual EU States. In a light of such a delicate situation, the EC has proposed that the distribution of the DP's financial envelopes between EU Member States be based on an arithmetic rule [50]. All Member States with direct payments per hectare below $90 \%$ of the EU average will close one third of the gap between their current direct payments level and $90 \%$ of the EU average in the course of the next period, but the allocation of direct payments for a period 2021-2027 still does not facilitate the conditions for the equal and fair distribution of DP's among Member States [51]. The 'external convergence' formula brought about a limited but unprecedented redistribution of the CAP direct payments financial envelopes among the Member States. However, it did not alter the relative ranking of countries, and there are still significant differences in payment rates per hectare; particularly, this is evident among the Old Member States and between the Old and New Member States [52]. The same mechanism has been repeated only with minor adjustments. The EC once again proposed the arithmetical formula, which is aimed at lowering gaps of direct payments financial aid between Member States in a period of 2021-2027: all Member States, those direct payments is below $90 \%$ of the EU average will be able to reduce the gap by half (rule of "closing the gap by $50 \%$ ") between $90 \%$ of the EU level and their respective level by 2027 [53]. Even using this new formula "by closing the gap by $50 \%$ " the Baltic countries remain largely disadvantaged in terms of direct payment financial support (Figure 1). 


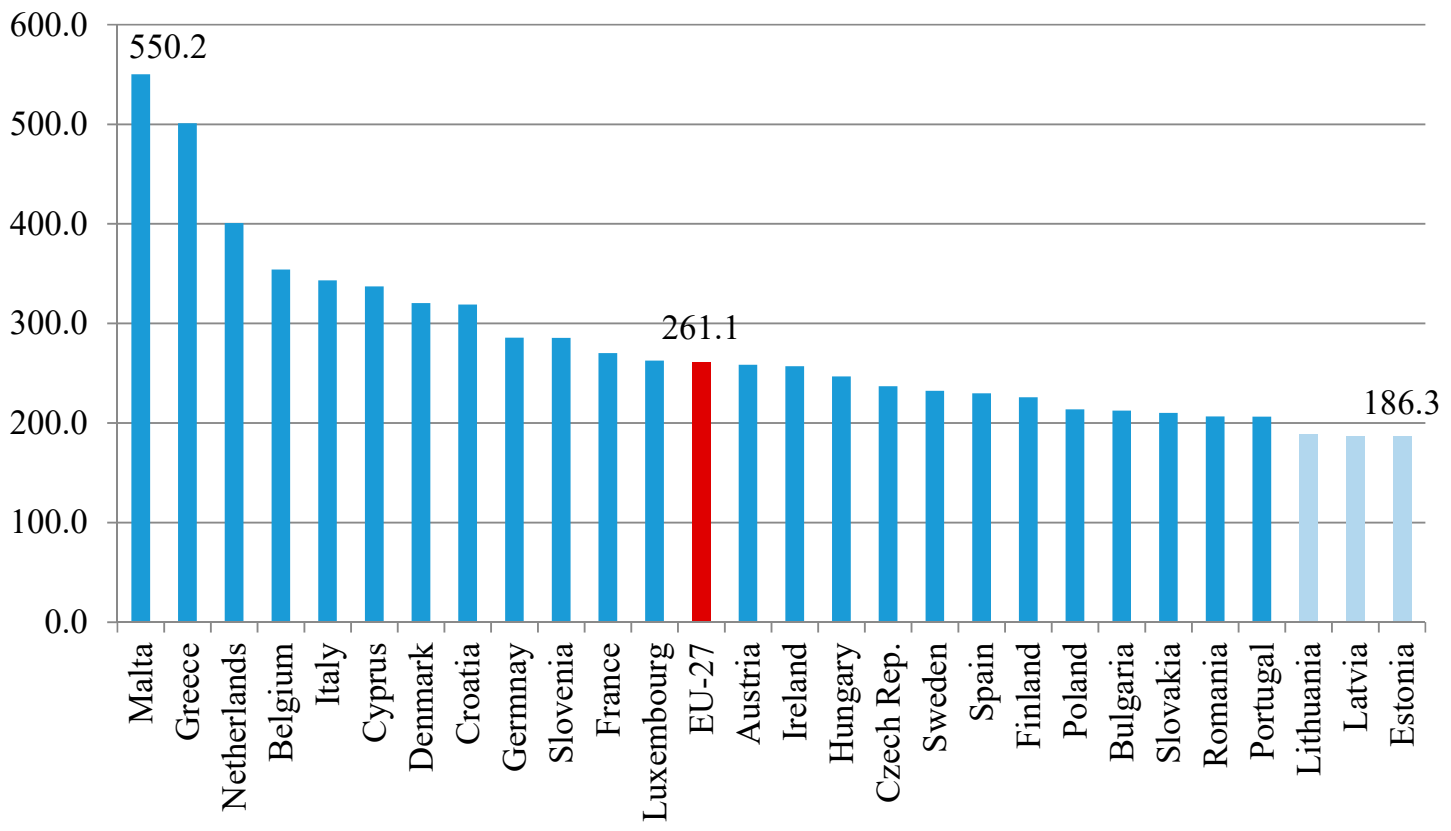

Figure 1. The average DP values as proposed by the European Commission for 2021-2027, Eur per ha of UUA under the rule "closing the gap by $50 \%$ ". Source: Own calculations in accordance with the EC data.

The equal distribution of direct payments financial support is of utmost importance as direct payments account to about one third of farmers' income, and often forms the whole farmers' profit [54]. It conditions the necessity to formulate new methodological principles, what would allow fairer distribution of EU budget revenues among its Member States. The ministers of the Baltic States and Poland have already called for fairness and equality among the Member States noting that the process towards full convergence of direct payments among the Member States needs to be completed $[55,56]$.

\section{Methodology}

Direct payments are a key element of the Common Agricultural Policy that provides income support for farmers and promotes sustainability and environmentally-friendly farming practices [57]. The loss of revenue is associated with the cost of production of a certain amount of agricultural output [58]. We propose a methodological approach that based on the main direct payments rationale-income coverage allows supporting those, whose costs are the biggest, or the smallest to EUR 1 of production. Nowadays, direct payments are justified in a number of ways, including addressing low farm incomes, support for EU food security, providing a safety net for farmers against unexpected market shocks, as compensation for higher regulatory standards and ensuring more sustainable management of natural resources [59]. However, the answer to the question, who must be more generously supported-the ones, who are more effective, thus awarding the entrepreneurial spirit and productivity, what contributes to increasing levels of GDP and general wealth, or those, who are lagging behind because of technological backwardness, less favourable climate conditions, etc. who are being left outside, as it is a competence of EU officials. We examine both scenarios (supporting more and less effective agricultural sectors) paying attention not only to convergence, but also to food security (supporting more dispersed food production reduces food insecurity risks caused by flooding, droughts, agricultural pests, etc. in more effective regions), availability (some ancient crops, such as buckwheat are ineffective to produce, but are important to maintaining traditional cuisine in particular countries), rural development and sustainability (through providing employment in less developed rural regions). In order to address these issues and pay attention to some externalities (for example: Malta's very unfavourable soil for agriculture, high population density in The Netherlands and northwestern Germany, characterized by high average salaries, requiring big amounts of fresh 
foods and etc., we assume, that some differences in direct payments values objectively may exist, but it should not exceed $100 \%$, otherwise it will be very hard to assure convergence.

The research methodology is related to the fact that regardless of the type and where the agricultural produce is grown, some countries are performing better in using its own resources to earn money from agricultural activities (values are being represented by Euros earned per ha of cultivated land) than others, taking into account the requirements and objectives of the CAP, which are the same for all countries.

Thus, in order to calculate the cost of production in agriculture, it is important to identify the reliable source of the data. For this purpose, the Eurostat database was chosen, which is recognized and supervised by the European Commission. Therefore, cost and income data are taken directly from the Eurostat database. Income in the research is identified as an output of the agricultural 'industry' (at basic prices). According to the Eurostat database, the costs incurred on the farm are grouped into 3 major groups: total production costs (intermediate consumption), external factors and depreciation (as fixed capital consumption) (Table 1).

Table 1. Classification of farm costs according Eurostat.

\begin{tabular}{ccc}
\hline Total Production Costs (Intermediate Consumption) (I) & External Factors (II) & Depreciation (III) \\
\hline Seeds and seedlings & & \\
Electricity & & \\
Gas & & \\
Other fuels and propellant & & \\
Other energy sources & Compensation of employees & Equipment \\
Plant protection products & Rents and other real estate rental & charges to be paid \\
Veterinary costs & Interests paid and received & Plantations \\
Feed for animals & & Others \\
Building maintenance costs & & \\
Equipment/material maintenance costs & & \\
Financial intermediation services, indirectly measured & & \\
Other operating costs & \\
\hline
\end{tabular}

These costs can be split into two groups, based on Eurostat methodology:

- $\quad$ Costs for 1 ha of potentially eligible area (PEA).

- Costs for 1 EUR of agricultural production.

In order to calculate direct payments values for EU Member States costs the data of the Multiannual Financial Framework for the years 2021-2027 (Brexit was taken into account) and the European Commission approved PEA area for the year 2016 were used. The data of farm costs was used from Eurostat 2014-2016 on average.

Using the above mentioned data sources the average estimated direct payments values $(\bar{I})$ for EU-27 for the period of 2021-2027 m. were calculated:

$$
\bar{I}=\frac{\sum_{i=1}^{27} \bar{V}_{i}}{\sum_{i=1}^{27} P_{i}},
$$

where $\bar{V}_{i}$-average direct payments financial envelope for the period of 2021-2027 for the i-th EU-27 Member State per year;

$P_{i}$-in 2016 officially approved potentially eligible area of the i-th EU-27 Member State, with:

$$
\bar{V}_{i}=\frac{\sum_{j=1}^{7} V_{i j}}{7}
$$


where $V_{i j}$-average direct payments financial envelope of $i$ Member state per 2021-2027 years. The data of envelope values for each EU-27 Member States for each year in a period 2021-2017 is presented in Appendix A (Table A1). Thus:

$$
V_{d}=\sum_{i=1}^{n} \bar{V}_{i}
$$

where $V_{d}$ is the total average annual direct payments financial envelope (EC proposal for year 2021-2027), here $\mathrm{n}=27$.

\section{Calculation of Direct Payments Values According Production and Cost Ratio Based on the Eurostat}

As one of the main CAP objectives is to provide farmers with direct payments to function as a safety net, making farming more profitable and guarantee food security in Europe [54], for the calculation of direct payments for the EU-27 Member States we employed a production costs methodology, which is widely used and adopted by the EC [60,61].

The production cost ratio (output over input, see Appendix A, Table A2) method allows to identify two aspects: 1) country's agricultural efficiency, i.e., how much does it cost to produce agricultural production worth 1 EUR and to compare it with other EU Member States; 2) The values of direct payments $\left(T I_{E s i}\right)$ based on production costs ratio in the context of EU-27 are obtained as follows:

$$
T I_{E s i}=\frac{\left[\frac{\left[\frac{S_{E i} * \frac{V_{d}}{Y_{E i}} \sum_{i=1}^{n} P_{i}}{*} P_{i}\right]}{\left[\frac{\sum_{i=1}^{n} S_{E i} Y_{d i} Y_{i=1} P_{i} * P_{i}}{V_{d}^{n}}\right]}\right.}{P_{i}}
$$

where $S_{E i}$-all costs incurred by all farms of the $i$ Member State in order to produce the agricultural production worth $Y_{E i}$ according Eurostat data.

These direct payments are estimated under the condition that higher direct payments are being paid to those countries where agriculture is less efficient, i.e., if the cost of producing agricultural products for a value of 1 EUR (in general) is more expensive, higher direct payments are to be paid.

However, there is a debate over the idea of supporting the more efficient agricultural entities, which is based on classical principles of regulation in economy [62]. In the latter case, direct payments would be distributed according to the following formula:

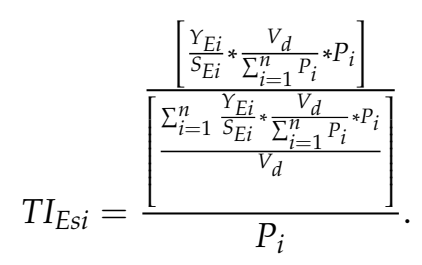

The aforementioned rules will be further illustrated by considering the real data for the EU Member States. This allows assessing the effects of relying on different assumptions for distribution of the direct payments.

\section{Results and Discussion}

The principle which accounts all the costs incurred by famers in generating an agriculture production is aimed at supporting less effective agricultural sectors in EU-27, experiencing not only lack in investment, technological development, but also struggling with not the most favourable climate or soil conditions. The rationale for supporting these lagging behind farming entities is based around arguments of supporting food production as close to the consumption points as possible in order to assure freshness, redistribution of food production among all EU Member States with the aim of food 
security, supporting employment in less developed rural regions and assuring the economic viability and sustainability of all rural regions within EU including proper land use to assure it's productivity for future generations. This method is also the most convergence inducing one.

Figure 2 shows that the biggest increase in direct payments values would be for Estonia, from 186.3 to 314.2 EUR/ha (a $69 \%$ increase). Slovakia's direct payments would increase by more than $63 \%$ compared to the EC proposal, i.e., from 210 to 343 EUR/ha; Finland's—-by $59 \%$ and would be the highest direct payments value among the EU-27 (358.8 EUR/ha). Lithuanian and Latvian direct payments values would also increase. According to this calculation, Lithuania's direct payments would amount to $260 \mathrm{EUR} / \mathrm{ha}$, i.e., would be $38 \%$ bigger than the EC proposal (189 EUR/ha) and $27.5 \%$ lower than the maximum direct payments value among the EU-27 countries (Finland). In Latvia, the amount of financial support would increase even more than in Lithuania-by $53 \%$, i.e., up to $286.1 \mathrm{EUR} / \mathrm{ha}$. The biggest decrease in direct payments compared to EC proposal would be in Malta-minus $66 \%$ (from 550.2 to $185.9 \mathrm{EUR} / \mathrm{ha}$ ) and would be the lowest among all EU countries, Greece would experience a cut of $57 \%$ (from 501 to 216.3 EUR/ha), Cyprus by minus 33\% (from 337.1 to $226 \mathrm{EUR} / \mathrm{ha}$ ) and The Netherlands-by minus 32\% (from 400.7 to 272.7 EUR/ha).

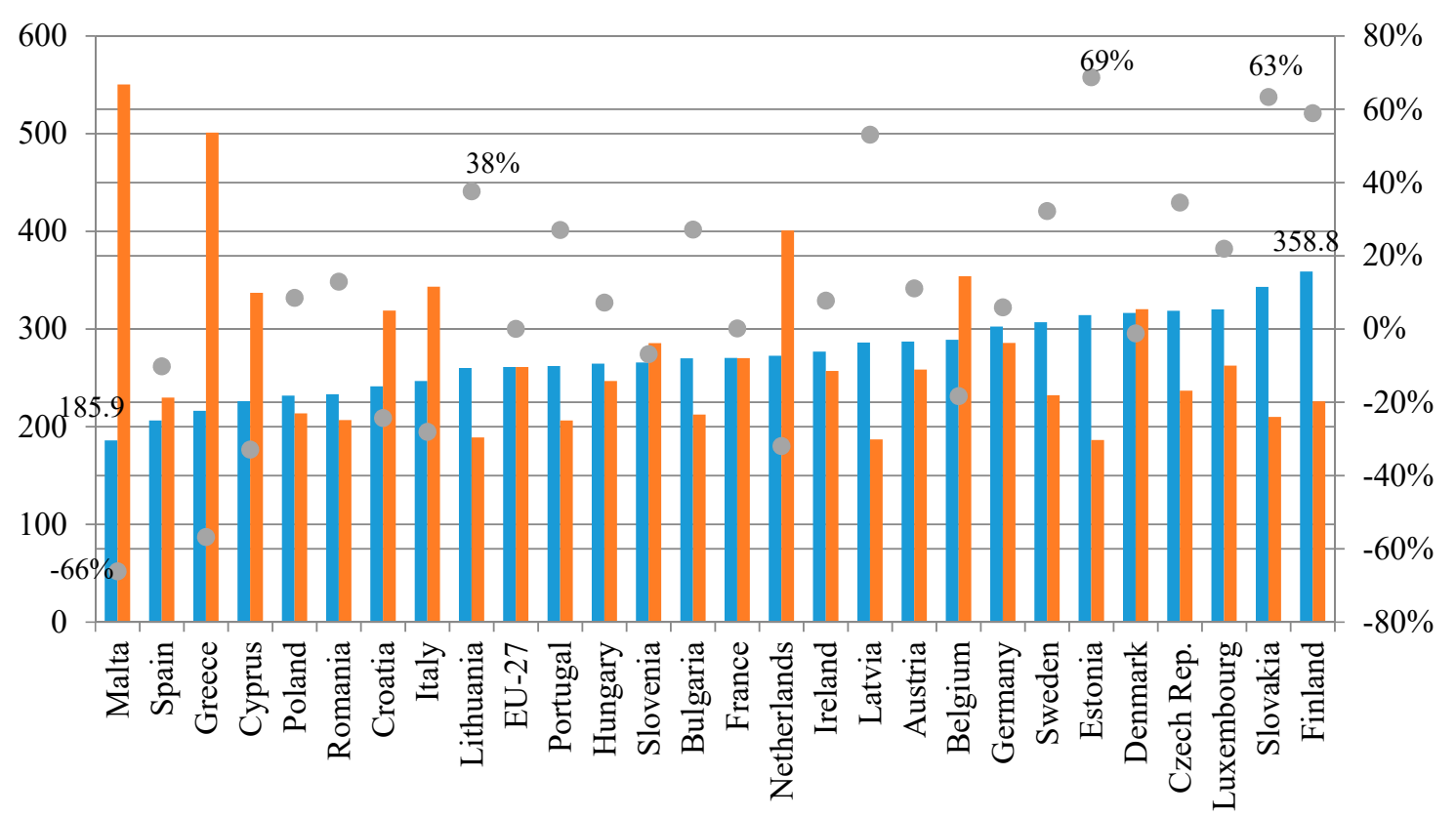

\footnotetext{
- Direct payments values based on average costs and production value ratio (supporting less effective*), EUR/ha - Average direct paymenyts values European Commission proposed for 2021-2027, EUR/ha - Change compared to the European Commission proposed
}

Figure 2. Average direct payments values for 2021-2027 based on average Eurostat costs and production value ratio in years 2014-2016 and the average direct payments values European Commission proposed for 2021-2027. * supporting less effective agricultural sectors means that our calculation provides more intensive support to countries where agricultural output/input ratio is less than 1 (see Appendix A, Table A2). Source: authors' calculation, according to Eurostat (2018) data.

The rationale for supporting more effective farming industries lay behind the classical economic principle of efficiency, broadly discussed in agricultural context [63-65]. Supporting its best performers, the EU could guarantee the biggest production efficiency, bigger profits and budget earnings, and the possibility to compete with other important market players in agriculture, not belonging to the EU (US, Canada, Turkey, Argentina and etc.), which also have its own agricultural support mechanisms [66]. Supporting the strongest and the most efficient ones also creates a basis for emergence of strong, 
self-sustaining agricultural sector within EU, which would allow gradually repealing the consumer of the biggest part of the EU budget pie-CAP and its direct payments.

Analysing the change in direct payments values under the support scheme for more effective ones, from Figure 3 we can see the biggest increase in Spain's direct payments values, from 229.8 to $324.1 \mathrm{EUR} / \mathrm{ha}$ (more than $41 \%$ ). Romania's direct payments value would increase from 206.6 to 286.7 EUR/ha (second biggest increase-39\%). The value of Lithuanian direct payments would also increase significantly (third in the EU-more than 36\% compared to the EC proposal), from 189 to 257.1 EUR/ha. In Latvia and Estonia, the direct payments would also increase, but not as rapidly as in case of supporting less efficient ones. According to this calculation, Latvia's direct payments would amount to EUR 233.7/ha, i.e., 25\% more than EC (187 EUR/ha). In Estonia, the financial support would increase less than in Latvia and Lithuania-by $14 \%$ compared to the EC proposed, i.e., up to $212.8 \mathrm{EUR} / \mathrm{ha}$. The biggest decrease in direct payments values compared to EC proposal would be experienced in the Netherlands-by minus 39\% (from 400.7 to $245.2 \mathrm{EUR} / \mathrm{ha}$ ), Greece-minus 38\% (from 501 to 309.2 EUR/ha), Malta by minus 35\% (from 550.2 to 359.7 EUR/ha). Anyway, Malta would still receive the highest rates among the EU-27 countries (reflecting unfavourable agricultural soil and the fact, that Malta is an island and food production here should be supported to overcome possible food shortages due to the possibility of emergency issues halting food supply by sea for some time). In Finland, the value of the direct payments would decrease by $17 \%$, i.e., from 225.8 to $186.3 \mathrm{EUR} / \mathrm{ha}$ and would be the lowest among all EU member states.

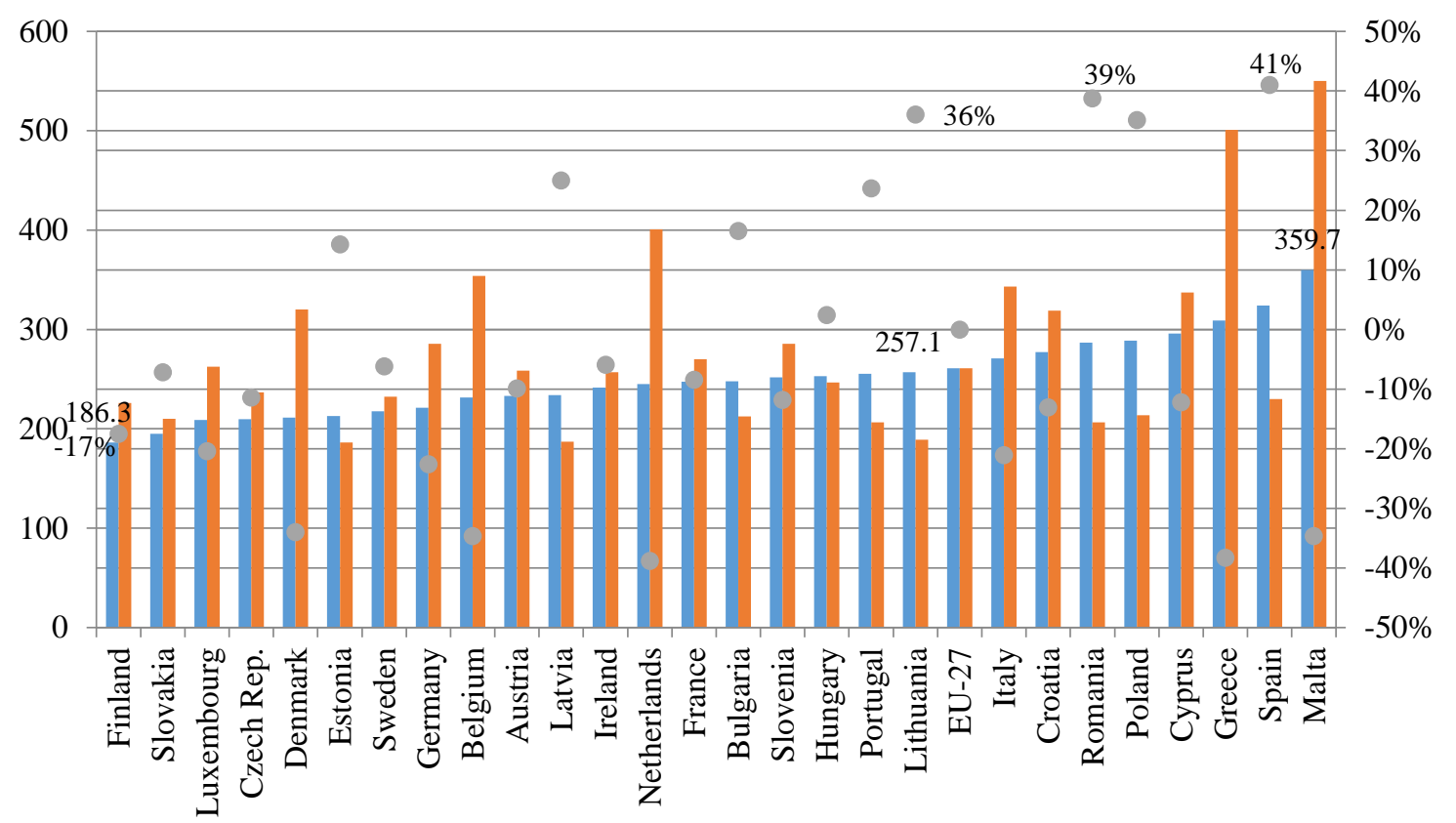

- Direct payments values based on average costs and production value ratio (supporting more effective*), EUR/ha - Average direct payments values European Commission proposed for 2021-2027, EUR/ha

- Change compared to the European Commission proposed

Figure 3. Average direct payments values for 2021-2027 based on average costs and production value ratio in years 2014-2016 and the average direct payments values European Commission proposed for 2021-2027. * supporting more effective agricultural sectors means that our calculation provides more intensive support to those countries, whose agricultural sectors output/input rate is more than 1 (see Appendix A, Table A2). Source: authors' calculation, according to Eurostat (2018) data.

As can be seen from Figures 2 and 3, in case of truly following CAP rules for the allocation of direct payments, as agreed by all EU Member States, regardless the method chosen (to support more or less effective agriculture) the distribution of DP's would be more fair and equal, than the current EC proposal, as in case of supporting less effective ones difference between lowest and biggest direct 
payments values would be $93.01 \%$, in case of supporting the most effective- $93.08 \%$, the current EC proposal creates a difference of $189.47 \%$ with no substantial explanation about the reasons for deviation from early agreed convergence plan.

\section{Conclusions}

The convergence process between Old and New EU Member States is lagging behind schedule. The current EC proposal for the allocation of direct payments values for the years 2021-2027 will not change the current trend, as is being based on the same methodological principles as previous programming periods that did not lead to a desired convergence path, or, in some cases, even allowed the manifestation of divergence.

In order to overcome these methodological deficiencies, leading to conflicts in the convergence process between Old and New EU Member States we support a new direct payments rationale, where financial aid is coupled with the average costs incurred in generating monetary value of agricultural products. Following this methodological approach, the direct payments under CAP not only would contribute to the convergence process among all EU Member States, but also would respond to other CAP challenges. Specifically, it would be able to ensure qualitative and safe food for all EU citizens, as it would allow spreading the cultivation of various crops into wider areas of EU, by providing an income support, thus lowering risk of such agricultural activity.

In case the income support mechanism would be implemented, it would also benefit to market self-regulating mechanism in the EU, as farmers would receive money only after they have sold their production. This would not only prevent the overproduction, that was very common in previous direct payments schemes under the CAP [67], but would also encourage farmers to search for niche products, what can be easily introduced into the market in order to fasten the financial flows. The increasing diversification of cultivated agricultural crops would also benefit to increasing resilience $[68,69]$ and sustainability [35] of rural regions, thus meeting yet another CAP objective.

Author Contributions: Methodology, A.V.; Writing—original draft, T.B. and M.M.; Writing—review \& editing, D.S.

Funding: This research received no external funding.

Conflicts of Interest: The authors declare no conflict of interest. 


\section{Appendix A}

Table A1. The direct payments envelope values for EU-27 Member States in a period 2021-2017.

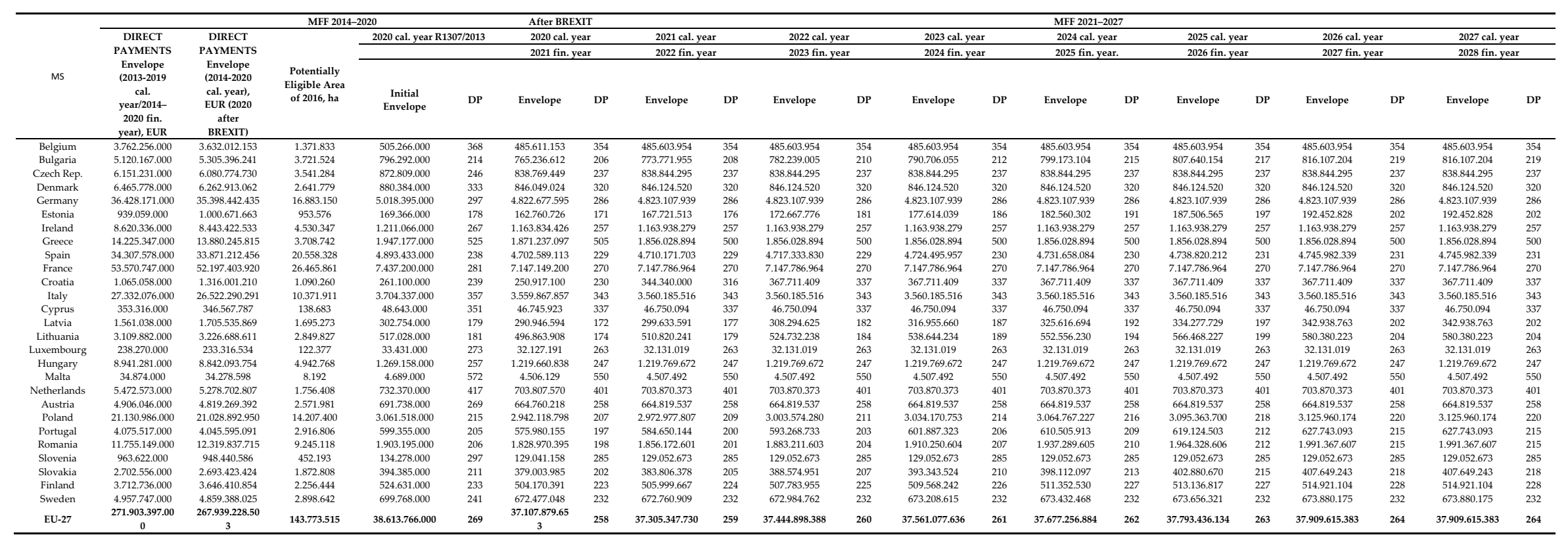

Source: European Commission, 2018. 
Table A2. 2014-2016 average costs and production value expressed through input and output of agricultural sectors in EU countries.

\begin{tabular}{|c|c|c|c|c|c|c|c|c|}
\hline \multirow[b]{2}{*}{ Country } & \multirow[b]{2}{*}{ Output/Input } & \multirow{2}{*}{$\begin{array}{c}\text { Output } \\
\text { Output of the } \\
\text { Agricultural 'Industry' }\end{array}$} & \multicolumn{6}{|c|}{ Input } \\
\hline & & & $\begin{array}{l}\text { Total Intermediate } \\
\text { Consumption }\end{array}$ & $\begin{array}{l}\text { Fixed Capital } \\
\text { Consumption }\end{array}$ & $\begin{array}{c}\text { Compensation of } \\
\text { Employees }\end{array}$ & $\begin{array}{l}\text { Rents and other real Estate } \\
\text { Rental Charges to be Paid }\end{array}$ & Interest Paid & $\begin{array}{l}\text { Interest } \\
\text { Received }\end{array}$ \\
\hline Finland & 0.832 & 4419.2 & 3230.6 & 1145.0 & 625.3 & 217.4 & 94.7 & 0.0 \\
\hline Slovakia & 0.870 & 2314.5 & 1747.4 & 255.2 & 547.1 & 71.1 & 43.2 & 4.2 \\
\hline Czech Republic & 0.937 & 4868.5 & 3336.1 & 623.2 & 983.8 & 227.3 & 47.6 & 20.8 \\
\hline Denmark & 0.943 & 10396.8 & 7859.1 & 1353.4 & 1043.3 & 491.9 & 382.5 & 110.8 \\
\hline Estonia & 0.950 & 861.7 & 604.2 & 119.5 & 132.0 & 32.6 & 19.7 & 0.9 \\
\hline Sweden & 0.972 & 6108.4 & 4377.9 & 1063.3 & 352.7 & 307.9 & 232.7 & 52.2 \\
\hline Germany & 0.987 & 54839.8 & 37270.7 & 9330.3 & 5003.9 & 2915.3 & 1118.8 & 68.0 \\
\hline Belgium & 1.033 & 8109.7 & 5879.0 & 799.0 & 642.3 & 231.9 & 298.2 & 0.0 \\
\hline Latvia & 1.043 & 1355.6 & 1012.0 & 114.9 & 142.0 & 23.1 & 9.0 & 1.6 \\
\hline Ireland & 1.079 & 7370.2 & 5081.5 & 793.5 & 497.5 & 215.0 & 245.9 & 0.0 \\
\hline Netherlands & 1.095 & 26954.8 & 16843.4 & 3712.8 & 2405.7 & 646.6 & 1148.8 & 132.0 \\
\hline France & 1.104 & 73645.7 & 45015.4 & 10518.5 & 7753.9 & 2670.8 & 783.4 & 24.8 \\
\hline Bulgaria & 1.105 & 4112.9 & 2403.3 & 401.5 & 399.8 & 492.0 & 35.4 & 11.0 \\
\hline Slovenia & 1.123 & 1241.9 & 743.9 & 258.1 & 78.1 & 19.9 & 6.4 & 0.7 \\
\hline Hungary & 1.128 & 8096.0 & 4785.5 & 926.8 & 1123.5 & 332.9 & 21.8 & 15.6 \\
\hline Portugal & 1.139 & 6959.9 & 4395.8 & 735.1 & 815.1 & 47.3 & 125.1 & 8.0 \\
\hline Lithuania & 1.148 & 2870.8 & 1824.0 & 289.7 & 309.6 & 70.2 & 8.0 & 0.3 \\
\hline Italy & 1.209 & 54521.9 & 23302.5 & 11996.4 & 7312.2 & 1492.6 & 975.3 & 0.0 \\
\hline Croatia & 1.237 & 2105.0 & 1225.1 & 309.5 & 112.9 & 40.0 & 25.0 & 11.3 \\
\hline Romania & 1.280 & 15893.3 & 9175.8 & 2525.4 & 480.0 & 158.1 & 90.3 & 9.3 \\
\hline Cyprus & 1.321 & 677.5 & 394.3 & 16.4 & 84.9 & 9.7 & 7.9 & 0.0 \\
\hline Greece & 1.380 & 10632.4 & 5247.8 & 1248.0 & 579.5 & 486.0 & 143.0 & 0.0 \\
\hline Spain & 1.447 & 45908.9 & 21099.8 & 5155.9 & 4001.1 & 1020.6 & 455.7 & 0.0 \\
\hline Malta & 1.606 & 127.3 & 66.9 & 7.1 & 4.1 & 0.6 & 0.6 & 0.0 \\
\hline
\end{tabular}




\section{References}

1. Annoni, P.; Weziak-Bialowolska, D. A measure to target antipoverty policies in the European Union regions. Appl. Res. Qual. Life 2016, 11, 181-207. [CrossRef] [PubMed]

2. Dall'Erba, S.; Fang, F. Meta-analysis of the impact of European Union Structural Funds on regional growth. Reg. Stud. 2017, 51, 822-832. [CrossRef]

3. European Commission. Agriculture in the European Union and the Member States-Statistical Factsheets 2017. Available online: https://ec.europa.eu/agriculture/statistics/factsheets_en (accessed on 9 May 2019).

4. Trondal, J.; Gänzle, S.; Leruth, B. Differentiated Integration and Disintegration in the European Union: State-of-the-Art and Ways for Future Research; University of Agder: Kristiansand, Norway, 2017.

5. Breidenbach, P.; Mitze, T.; Schmidt, C.M. Eu Structural Funds and Regional Income Convergence: A Sobering Experience; Ruhr Economic Papers, No. 608; Rheinisch-Westfälisches Institut für Wirtschaftsforschung (RWI): Essen, Germany, 2016.

6. Tocco, B.; Davidova, S.; Bailey, A. The Impact of CAP Payments on the Exodus of Labour from Agriculture in Selected EU Member States; Factor Markets, Centre for European Policy Studies: Brussels, Belgium, 2013.

7. Gorton, M.; Douarin, E.; Davidova, S.; Latruffe, L. Attitudes to agricultural policy and farming futures in the context of the 2003 CAP reform: A comparison of farmers in selected established and new Member States. J. Rural Stud. 2008, 24, 322-336. [CrossRef]

8. Csaba, L. Crisis in Economics: Studies in European Political Economy; Akadémiai kiadó: Budapest, Hungary, 2009.

9. Macartney, H. Variegated Neoliberalism: Eu Varieties of Capitalism and International Political Economy; Routledge: New York, NY, USA, 2010; 208p.

10. Diaz del Hoyo, J.L.; Dorrucci, E.; Heinz, F.F.; Muzikarova, S. Real Convergence in the Euro Area: A Long-Term Perspective; ECB Occasional Paper, No. 203; European Central Bank (ECB): Frankfurt, German, 2017.

11. Barrett, G. European economic governance: Deficient in democratic legitimacy? J. Eur. Integr. 2018, 40, 249-264. [CrossRef]

12. Quiroga, S.; Suárez, C.; Fernández-Haddad, Z.; Philippidis, G. Levelling the playing field for European Union agriculture: Does the Common Agricultural Policy impact homogeneously on farm productivity and efficiency? Land Use Policy 2017, 68, 179-188. [CrossRef]

13. European Commission. Income Support Explained Overview of Direct Payments for Farmers 2017. Available online: https://ec.europa.eu/info/food-farming-fisheries/key-policies/common-agricultural-policy/incomesupport/income-support-explained (accessed on 3 April 2019).

14. Coleman, W.D.; Grant, W.P. Policy convergence and policy feedback: Agricultural finance policies in a globalizing era. Eur. J. Political Res. 1998, 34, 225-247. [CrossRef]

15. Hansen, H.; Teuber, R. Assessing the impacts of EU's common agricultural policy on regional convergence: Sub-national evidence from Germany. Appl. Econ. 2011, 43, 3755-3765. [CrossRef]

16. Pálné Kovács, I. Cohesion Policy in Central and Eastern Europe: The Challenge of Learning. In Handbook on Cohesion Policy in the EU; Piattoni, S., Polverari, L., Eds.; Edward Elgar Publishing: Cheltenham, UK, 2016; pp. 302-322.

17. Muravska, T.; Aprāns, J.; Dahs, A. Cohesion policy in the sparsely populated countries. In Handbook on Cohesion Policy in the EU; Piattoni, S., Polverari, L., Eds.; Edward Elgar Publishing: Cheltenham, UK, 2016; pp. 285-301.

18. Czyżewski, B.; Matuszczak, A.; Miśkiewicz, R. Public goods versus the farm price-cost squeeze: shaping the sustainability of the EU's common agricultural policy. Technol. Econ. Dev. Eco. 2019, 25, 82-102. [CrossRef]

19. Boulanger, P.; Philippidis, G. The EU budget battle: Assessing the trade and welfare impacts of CAP budgetary reform. Food Policy 2015, 51, 119-130. [CrossRef]

20. Papadopoulos, A.G. The impact of the CAP on agriculture and rural areas of EU member states. Agrar. South J. Political Econ. 2015, 4, 22-53. [CrossRef]

21. Pellegrini, G.; Terribile, F.; Tarola, O.; Muccigrosso, T.; Busillo, F. Measuring the effects of European Regional Policy on economic growth: A regression discontinuity approach. Pap. Reg. Sci. 2013, 92, 217-233. [CrossRef]

22. Gagliardi, L.; Percoco, M. The impact of European Cohesion Policy in urban and rural regions. Reg. Stud. 2017, 51, 857-868. [CrossRef] 
23. Barwise, A.; Juhn, Y.J.; Wi, C.I.; Novotny, P.; Jaramillo, C.; Gajic, O.; Wilson, M.E. An Individual Housing-Based Socioeconomic Status Measure Predicts Advance Care Planning and Nursing Home Utilization. Am. J. Hosp. Palliat. Med. 2018, 36. [CrossRef] [PubMed]

24. Wójcik, P. Was Poland the next Spain? Parallel analysis of regional convergence patterns after accession to the European Union. Equilib. Q. J. Econ. Econ. Policy 2017, 12, 593-611. [CrossRef]

25. Becker, S.O.; Egger, P.H.; von Ehrlich, M. Effects of EU Regional Policy: 1989-2013. Reg. Sci. Urban Econ. 2018, 69, 143-152. [CrossRef]

26. Muscio, A.; Reid, A.; Rivera Leon, L. An empirical test of the regional innovation paradox: Can smart specialisation overcome the paradox in Central and Eastern Europe? J. Econ. Policy Reform 2015, 18, 153-171. [CrossRef]

27. Baráth, L.; Fertő, I. Productivity and convergence in European agriculture. J. Agric. Econ. 2017, 68, $228-248$. [CrossRef]

28. Poznańska, J.; Poznański, K. Comparison of patterns of convergence among "emerging markets" of Central Europe, Eastern Europe and Central Asia. Comp. Econ. Res. 2015, 18, 5-23. [CrossRef]

29. Gaynor, K.B.; Karakitsos, E. Economic Convergence in a Multispeed Europe; Springer: New York, NY, USA, 2016.

30. Iammarino, S.; Rodriguez-Pose, A.; Storper, M. Regional inequality in Europe: Evidence, theory and policy implications. J. Econ. Geogr. 2018, 19, 273-298. [CrossRef]

31. Staehr, K. Economic growth and convergence in the baltic states: Caught in a middle-income trap? Intereconomics 2015, 50, 274-280. [CrossRef]

32. Feher, A.; Goșa, V.; Raicov, M.; Harangus, D.; Condea, B.V. Convergence of Romanian and Europe Union agriculture-evolution and prospective assessment. Land Use Policy 2017, 67, 670-678. [CrossRef]

33. Läpple, D.; Renwick, A.; Thorne, F. Measuring and understanding the drivers of agricultural innovation: Evidence from Ireland. Food Policy 2015, 51, 1-8. [CrossRef]

34. Galluzzo, N. The Common Agricultural Policy and employment opportunities in Romanian rural areas: The role of agritourism. Bulg. J. Agric. Sci. 2017, 23, 14-21.

35. Volkov, A.; Balezentis, T.; Morkunas, M.; Streimikiene, D. Who Benefits from CAP? The Way the Direct Payments System Impacts Socioeconomic Sustainability of Small Farms. Sustainability 2019, 11, 2112. [CrossRef]

36. Ciaian, P.; Kancs, D.A.; Espinosa, M. The impact of the 2013 CAP reform on the decoupled payments' capitalisation into land values. J. Agric. Econ. 2018, 69, 306-337. [CrossRef]

37. Greer, A. Post-exceptional politics in agriculture: An examination of the 2013 CAP reform. J. Eur. Public Policy 2017, 24, 1585-1603. [CrossRef]

38. Kijek, A.; Kijek, T.; Nowak, A.; Skrzypek, A. Productivity and its convergence in agriculture in new and old European Union member states. Agric. Econ. 2019, 65, 1-9. [CrossRef]

39. Severini, S.; Biagini, L.; Finger, R. Modeling agricultural risk management policies-The implementation of the Income Stabilization Tool in Italy. J. Policy Model. 2019, 41, 140-155. [CrossRef]

40. Trestini, S.; Giampietri, E.; Boatto, V. Toward the implementation of the Income Stabilization Tool: An analysis of factors affecting the probability of farm income losses in Italy. New Medit 2017, 16, 24-30.

41. European Commission. Agriculture Statistics-Family Farming in the EU 2017. Available online: https: //ec.europa.eu/eurostat/statistics-explained/index.php/Agriculture_statistics_-_family_farming_in_the_EU (accessed on 11 May 2019).

42. Henke, R.; Severini, S.; Sorrentino, A. From the Fischler reform to the future CAP. In The Common Agricultural Policy after the Fischler Reform: National Implementations, Impact Assessment and the Agenda for Future Reforms; Routledge: New York, NY, USA, 2011; 544p.

43. Vera, A.C.; Colmenero, A.G. Evaluation of risk management tools for stabilising farm income under CAP 2014-2020. Econ. Agrar. Y Recur. Nat. 2017, 17, 3-23.

44. European Commission. Annual EU Budget 2019. Available online: https://ec.europa.eu/info/about-europeancommission/eu-budget/documents/annual-budget/2019_en (accessed on 27 April 2019).

45. Latruffe, L.; Davidova, S.; Douarin, E.; Gorton, M. Farm expansion in Lithuania after accession to the EU: The role of CAP payments in alleviating potential credit constraints. Eur. Asia Stud. 2010, 62, 351-365. [CrossRef]

46. Hartmann, M.; Frohberg, K. Baltic Agricultural Competitiveness and Prospects under European Union Accession. In Agriculture and East-West European Integration; Hartell, J.G., Swinnen, J.F.M., Eds.; Routledge: London, UK, 2017; pp. 33-64. 
47. European Commission. CAP Post-2013: Key Graphs \& Figures: Share of Direct Payments and Total Subsidies in Agricultural Factor Income; DG Agriculture and Rural Development, Agricultural Policy Analysis and Perspectives Unit: Brussels, Belgium, 2017.

48. Zekić, S.; Matkovski, B. New CAP reform and Serbian agriculture. In Proceedings of the Sustainable Agriculture and Rural Development in Terms of the Republic of Serbia Strategic Goals Realization within the Danube Region, Rural Development and (UN) Limited Resources, Belgrade, MT, USA, 5-6 June 2014.

49. Sinabell, F.; Schmid, E.; Hofreither, M.F. Exploring the distribution of direct payments of the Common Agricultural Policy. Empirica 2013, 40, 325-341. [CrossRef]

50. European Council. Cover Note Conclusions (Multiannual Financial Framework). 2013. Available online: http://data.consilium.europa.eu/doc/document/ST-37-2013-INIT/en/pdf (accessed on 12 May 2019).

51. Matthews, A. The CAP in the 2021-2027 MFF Negotiations. Intereconomics 2018, 53, 306-311. [CrossRef]

52. European Parliament. Research for AGRI Committee-CAP Reform post-2020-Challenges in Agriculture. Study 2016. Available online: http://www.europarl.europa.eu/RegData/etudes/STUD/2016/585898/IPOL_ STU(2016)585898_EN.pdf (accessed on 15 June 2019).

53. European Commission. EU Budget: Commission Proposes a Modern Budget for a Union that Protects, Empowers and Defends. Press Release. Available online: http://europa.eu/rapid/press-release_IP-18-3570_en. htm (accessed on 12 February 2019).

54. European Commission CAP Explained Direct Payments for Farmers 2015-2020. Available online: https://ec.europa.eu/agriculture/sites/agriculture/files/direct-support/direct-payments/docs/directpayments-schemes_en.pdf (accessed on 11 June 2019).

55. Tamm, T. Estonia asks for Uniform Direct Payments to EU Farmers. Press Release of Minister of Rural Affairs of Estonia. 2018. Available online: https://news.err.ee/691191/estonia-asks-for-uniform-direct-payments-toeu-farmers (accessed on 14 June 2019).

56. De Lauwere, C.; Malak-Rawlikowska, A.; Stalgiene, A.; Klopcic, M.; Kuipers, A. Entrepreneurship and Competencies of Dairy Farmers in Lithuania, Poland and Slovenia. Transform. Bus. Econ. 2018, 17, $237-257$.

57. European Commission. EU Budget: The Common Agricultural Policy beyond 2020 Press Release. Available online: http://europa.eu/rapid/press-release_MEMO-18-3974_en.htm (accessed on 11 January 2019).

58. Debertin, D.L. Agricultural Production Economics. In Agricultural Economics Textbook Gallery, 3rd ed.; University of Kentucky: Lexington, KY, USA, 2014.

59. Matthews, A. Does Capping Direct Payments Make Sense. In CAP Reform. Eu. 2017. Available online: http://capreform.eu/does-capping-direct-payments-make-sense/ (accessed on 02 June 2019).

60. Nas, T.F. Cost-Benefit Analysis: Theory and Application, 2nd ed.; Lexington Books: London, UK, 2016; p. 252.

61. Buller, H.; Wilson, G.A.; Holl, A. Agri-Environmental Policy in the European Union; Routledge: London, UK, 2017.

62. Posner, R.A. Theories of Economic Regulation. NBER Working Paper. 1974. Available online: https: //www.nber.org/papers/w0041.pdf (accessed on 15 June 2019).

63. Hall, B.F.; LeVeen, E.P. Farm size and economic efficiency: The case of California. Am. J. Agric. Econ. 1978, 60, 589-600. [CrossRef]

64. Chavas, J.P.; Aliber, M. An analysis of economic efficiency in agriculture: A nonparametric approach. J. Agric. Resour. Econ. 1993, 18, 1-16.

65. Álvarez, A.; del Corral, J.; Solís, D.; Pérez, J.A. Does intensification improve the economic efficiency of dairy farms? J. Dairy Sci. 2008, 91, 3693-3698. [CrossRef]

66. Sharma, S.K. Domestic Support Under Agreement on Agriculture. In The WTO and Food Security; Springer: Singapore, 2016; pp. 15-26.

67. Grant, W. The Common Agricultural Policy; Macmillan International Higher Education: London, UK, 1997; 256p.

68. Morkūnas, M.; Volkov, A.; Pazienza, P. How resistant is the agricultural sector? Economic resilience exploited. Econ. Sociol. 2018, 11, 321-332. [CrossRef]

69. Pandey, B.; Bandyopadhyay, P.; Kadam, S.; Singh, M. Bibliometric study on relationship of agricultural credit with farmer distress. Manag. Environ. Qual. 2018, 29, 278-288. [CrossRef]

(C) 2019 by the authors. Licensee MDPI, Basel, Switzerland. This article is an open access article distributed under the terms and conditions of the Creative Commons Attribution (CC BY) license (http://creativecommons.org/licenses/by/4.0/). 